\title{
Safety Profile of Caesalpinia spinosa Aqueous Extract Tested in Oreochromis niloticus Toward Its Application in Dermocosmetics
}

\begin{abstract}
David Salirrosas ${ }^{1}$, Nataly Reategui-Pinedo ${ }^{1}$, Jan Pier Crespo ${ }^{1}$, Linda Sánchez-Tuesta ${ }^{1}$, Mónica Arqueros ${ }^{1}$, Angelita Cabrera ${ }^{1}$, Renata Miliani Martinez ${ }^{2}$, Carmen Ayala ${ }^{1}$, André Rolim Baby ${ }^{2 *}$ and Zulita Adriana Prieto ${ }^{1 *}$

${ }^{1}$ Laboratory Genetics and Molecular Biology, Universidad Nacional de Trujillo, Trujillo, Peru, ${ }^{2}$ Laboratory of Cosmetology, Department of Pharmacy, School of Pharmaceutical Sciences, University of São Paulo, São Paulo, Brazil
\end{abstract}

\section{OPEN ACCESS}

Edited by:

Mitali Sarkar

Chung-Ang University, South Korea

Reviewed by:

Arunava Majumder,

Lovely Professional University, India

Manuel II Garcia-Ulloa,

National Autonomous University of

Mexico, Mexico

*Correspondence:

Zulita Adriana Prieto

zprieto@unitru.edu.pe

André Rolim Baby

andrerb@usp.br

Specialty section:

This article was submitted to

Sustainable Supply Chain

Management,

a section of the journal

Frontiers in Sustainability

Received: 16 April 2021

Accepted: 22 July 2021

Published: 23 August 2021

Citation:

Salirrosas D, Reategui-Pinedo N, Crespo JP, Sánchez-Tuesta L, Arqueros M, Cabrera A, Martinez RM, Ayala C, Baby AR and Prieto ZA (2021) Safety Profile of Caesalpinia spinosa Aqueous Extract Tested in Oreochromis niloticus Toward Its Application in Dermocosmetics.

Front. Sustain. 2:696289 doi: 10.3389/frsus.2021.696289
Herbal extracts have been widely used in dermocosmetics as a source of biomolecules and also as a natural claim. Fruits from Caesalpinia spinosa show great potential for their polyphenolic content, preservative, and film-forming features, as previously reported in specialized literature; however, the toxicity requires investigation. We explored Oreochromis niloticus (tilapia) in larval, alevins, and juvenile stages to evaluate the ex vivo and in vivo genotoxicity and in vivo acute and chronic toxicity of $C$. spinosa aqueous extract in different concentrations. Cytotoxicity, animal behavior, morphological deformities, and DNA damage were evaluated. Our results showed genotoxic effect in ex vivo tests, but no DNA damage in in vivo erythrocytes. We suggest a mechanism of cell permeability involved in the toxicity of $C$. spinosa aqueous extract. Internal validation showed the feasibility of $O$. niloticus applied for toxicity evaluation. Further studies could contribute for better understanding the uses and safety of $C$. spinosa in cosmetics and topical pharmaceutical products.

Keywords: Caesalpinia spinosa, Oreochromis niloticus, herbal extract, natural cosmetic, safety

\section{INTRODUCTION}

The largest sources of bioactive compounds in the pharmaceutical and cosmetic industries are derived from plants because of their intrinsic characteristics and presumed safety. Cultivable plants that ensure sustainability in quality and quantity and a reduced negative environmental impact are generally preferred (Lubbe and Verpoorte, 2011). Caesalpinia spinosa "tara" is a native species of Peru, with both wild types and those cultivated in various types of soils, from neutral to saline. These plants are resistant to drought and are able to adapt to temperature variations (Lubbe and Verpoorte, 2011). The leaves and fruits contain a high concentration of tannins, ranging from $26.4 \%$ to $60.0 \%$ (Goycochea, 2010) (water-soluble type equivalent to $55.1 \mathrm{~g}$ of gallotannins in $100 \mathrm{~g}$ of tara pods) (Chambi et al., 2013). Variations in the content of polyphenols and flavonoids with antioxidant activity have been reported according to the type of extract (aqueous or ethanolic) (Skowyra et al., 2013). Previous studies have demonstrated that the aqueous extract of tara has an $\mathrm{IC}_{50}$ value of antioxidants greater than that of ascorbic acid (Callohuari et al., 2017) and is able to control the degradation of hyaluronan (Valachová et al., 2014). In addition to the antioxidant 
profile, C. spinosa extract contains active compounds for the control of gram-positive and gram-negative bacteria, established by in vitro (Aguilar-Galvez et al., 2014) and in vivo treatment of tilapia infected with Flavobacterium columnare (Prieto et al., 2018). From the isolation of the bioactive fraction of the extract, two compounds, methyl gallate and gallic acid, were identified as responsible for the bacterial inhibition of Salmonella typhi, Listeria monocytogenes, and Staphylococcus aureus (OlmedoJuárez et al., 2019). This evidence allowed us to consider the use of C. spinosa extracts in cosmetic formulations not only as a preservative, but also for inducing the formation of a protective film on the surface of human skin (film-forming effect), reducing moisture loss and skin peeling. A mixture of extracts from Kappaphycus alvarezii and C. spinosa improved the sensory characteristics and smoothness of the skin when vehiculated in a cosmetic form (de Melo and Maia Campos, 2019).

C. spinosa has also been shown to have antitumor activity when evaluated in vitro in tumor cells. The ethanolic extract induced changes in the morphology of the cell membrane, presence of necrotic cells, loss of mitochondrial membrane potential, nuclear fragmentation, and induction of apoptosis (Castaneda et al., 2012). The cytotoxic effect of C. spinosa extract was reported in cell lines with multidrug-resistant profiles, and in mice with breast cancer, a synergistic effect was observed in the reduction of neoplastic cells with the combined application of doxorubicin and C. spinosa extract (Sandoval et al., 2016). It favors the activation of the immune response that allows for a better prognosis in the elimination of tumor cells from mice with breast cancer (Urueña et al., 2020). Additionally, modulation of the expression of the ligand protein involved in important immune checkpoints in personalized cancer therapy was evaluated, which suggested that the C. spinosa extract effects are promising for the treatment of many types of cancer (Lasso et al., 2020).

In a recent study, the absence of toxicity, genotoxicity, and mutagenicity of the C. spinosa ethanolic extract (P2Et) was demonstrated in healthy mice through in vivo tests. Micronucleus values were observed even below the negative control in groups that received oral P2Et. Similarly, the Ames test showed no mutagenicity in Salmonella typhimurium cultures (BallesterosRamírez et al., 2021). Considering this scenario with the purpose of determining the safety of the use of natural extracts as additives in cosmetic formulations, and taking into account that "tilapia" (Oreochromis niloticus) has a highly sensitive biological system in genotoxicity tests (Skowyra et al., 2013), we investigated the cytotoxic and genotoxic effect of the C. spinosa aqueous extract ex vivo and the absence of toxicity and genotoxicity in in vivo tests in healthy individuals of $O$. niloticus.

\section{MATERIALS AND METHODS}

\section{Biological Material}

The dried fruits (pods) of C. spinosa were collected from a crop in Chao, La Libertad, Peru $\left(8^{\circ} 36 / 49.47^{\prime \prime}\right.$ S, $78^{\circ} 43 / 51.61^{\prime \prime}$ W) in December 2020 (Figure 1). Botanical identification was carried out in the Herbarium Truxillense (HUT) of the National
University of Trujillo (registration code $\mathrm{N}^{\circ}$ 60715, Caesalpinia spinosa "tara").

Larvae, 5 to 10 days old, 15 day-old fingerlings, and 3 monthold juveniles of $O$. niloticus from the Experimental Genetics Center of the National University of Trujillo $\left(8^{\circ} 6 / 44.66^{\prime \prime} \mathrm{S}\right.$, $79^{\circ} 2 / 19.52^{\prime \prime}$ W) were used. This study was approved by the Ethics Committee under consubstantiate report number R.D.N ${ }^{\circ}$ 051-2016-Fac.CC.BB.Oficio Nº 010-2021-CE-Fac.CC.BB/UNT.

\section{Aqueous Extraction of C. spinosa}

The extract was prepared via infusion, with distilled water as the solvent. A total of $200 \mathrm{~g}$ of C. spinosa fruits (pods without removal of seeds) was introduced into $1 \mathrm{~L}$ of distilled water and placed in an oven at $55^{\circ} \mathrm{C} \pm 1^{\circ} \mathrm{C}$ for $7 \mathrm{~h}$. After which time, it was filtered with Whatman paper $\mathrm{N}^{\circ} 1$ and followed by a second filtration with a $1.0-\mu \mathrm{m}$ pore size filter, using a vacuum pump. The extract was concentrated in a rotary evaporator at $60^{\circ} \mathrm{C}$ and dried in an oven at $50^{\circ} \mathrm{C}$ (Bouabid et al., 2018). The percent yield (\% w/w) was calculated using Eq. (1) (Mohammad-Azmin and Mat-Nor, 2020).

\%yield = weight of dry extract $(\mathrm{g}) \times 100 /$ weight of dry fruit $(\mathrm{g})$

\section{Ex vivo Cytotoxicity Assay of C. spinosa Extract in O. niloticus Blood Cells}

Blood was obtained from the caudal vein of the fish $(0.1 \mathrm{ml})$ with a heparinized syringe and immediately mixed with fetal bovine serum (FBS) at a ratio of 1:100 $\mu \mathrm{l}(\mathrm{v} / \mathrm{v})$. The previously prepared cell suspension was distributed into seven groups at a volume of $40 \mu l$ per tube. Immediately, $10 \mu l$ of $C$. spinosa aqueous extract was added to each treatment. Final concentrations were 50.0, $20.0,10.0,2.0,1.0,0.5$, and $0.0 \mu \mathrm{g} / \mu \mathrm{l}$. After $1 \mathrm{~h}$ of treatment, $20 \mu \mathrm{l}$ of the sample was used to determine the percentage of cell mortality using propidium iodide stain. A fluorescence microscope (Olympus BX51 microscope, Japan, $400 \times$ ) was used. The number of cells evaluated was $>1,000$. The percentage viability and mean lethal dose $\left(\mathrm{LD}_{50}\right)$ were determined. Before the test, it was necessary to standardize and achieve internal validation of the three basic processes. The viability of blood cells is required to be maintained for periods of at least 2 to $3 \mathrm{~h}$, which is the time that an ex vivo experimental trial could last. In this regard, achieving a viability of over $90 \%$ was only possible using FBS by mixing the blood immediately after collection from the fish. In our previous tests, PBS and Hank's solutions were used; however, a mortality rate of more than $50 \%$ of blood cells was registered. Another internal validation was the sufficiency of the amount of the blood sample due to the total presence of nucleated cells. We only recommended $1 \mu \mathrm{l}$ per 60 to $100 \mu \mathrm{l}$ of FBS, as higher amounts of blood prevent individual cells from being evaluated. Finally, for the lysis process, lithium hydroxide was used instead of sodium hydroxide.

\section{Ex vivo Genotoxicity Assessment of $C$. spinosa in O. niloticus Blood Cells}

Cellular samples of peripheral blood from the caudal vein of $O$. niloticus were used. They were suspended in FBS and exposed 


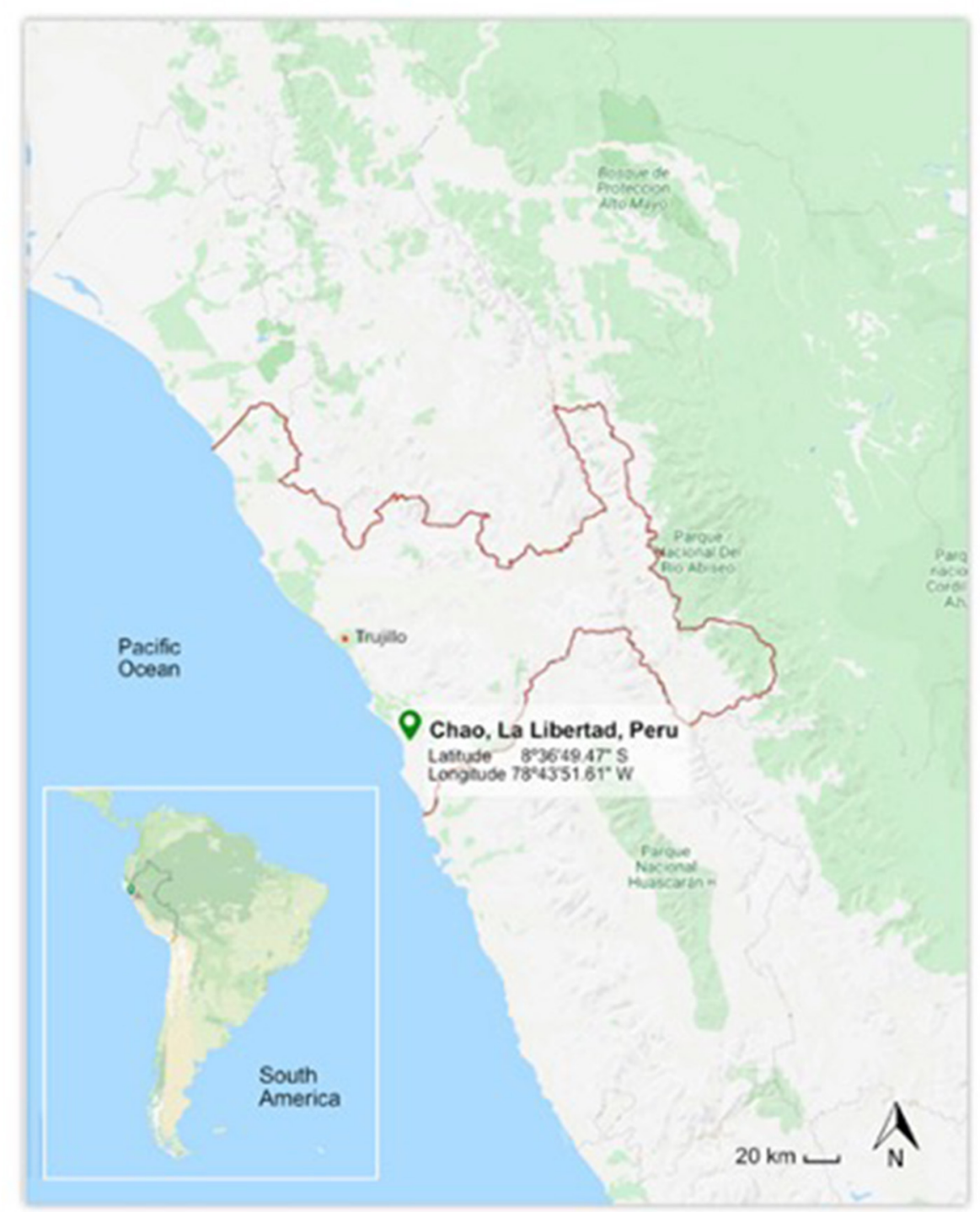

FIGURE 1 | Crops where the dried fruits of Caesalpinia spinosa were collected, on December 5, 2020.

to C. spinosa aqueous extract concentrations of $10.0,2.0$, and 1.0 $\mu \mathrm{g} / \mu \mathrm{l}$, as well as negative (FBS) and positive (cyclophosphamide $1.25 \mu \mathrm{g} / \mathrm{ml})$ controls. For this test, only concentrations with a viability $>90 \%$ were considered.

\section{Comet Test}

Forty microliters of each diluted sample $(1.0 \mu \mathrm{l}$ in $100 \mu \mathrm{l}$ of FBS) was suspended in $95 \mu \mathrm{l}$ of low melting agarose (LMPA) at a final concentration of $0.7 \%$ and immediately placed on a previously impregnated thin layer on a slide and incubated at $4^{\circ} \mathrm{C}$ for $15 \mathrm{~min}$. Cell lysis $(2.5 \mathrm{M} \mathrm{NaCl}, 100 \mathrm{mM}$ EDTA, $10 \mathrm{mM}$ Tris base, $1 \%$ Triton $\mathrm{X}-100,10 \% \mathrm{DMSO}$, and $\mathrm{pH} 10$, adjusted with lithium hydroxide) was continued for $1 \mathrm{~h}$, followed by alkaline electrophoresis $(\mathrm{pH}>13.5$ at $20 \mathrm{~V}$ and $300 \mathrm{~mA}$ for $30 \mathrm{~min}$ at $4^{\circ} \mathrm{C}$ in a buffer of $1 \mathrm{mM} \mathrm{Na}_{2}$ EDTA and $0.3 \mathrm{M} \mathrm{NaOH}$ ). After neutralization by rinsing three times with $0.4 \mathrm{M}$ Tris buffer at $\mathrm{pH}$ 7.5, the slides were stained with Sybr Gold and observed under a fluorescence microscope (Olympus BX51 microscope, Japan, $400 \times$ ) (Hussain et al., 2018; Bivehed et al., 2020).

\section{In vivo Acute Toxicity Test and Chronic Toxicity Test of C. spinosa in $O$. niloticus}

Tilapia larvae's acute toxicity assay (Capela et al., 2019). Tilapia larvae were obtained from the oral cavity of females and randomly distributed into fish incubators ( $~ 300$ individuals per treatment). Each incubator was maintained with a continuous aerated water flow at $25 \pm 1{ }^{\circ} \mathrm{C}$. After $48 \mathrm{~h}$ of adaptation, the experiment began with four experimental groups: positive control (cyclophosphamide, $1.25 \mu \mathrm{g} / \mathrm{ml}$ ) and 


\section{A}

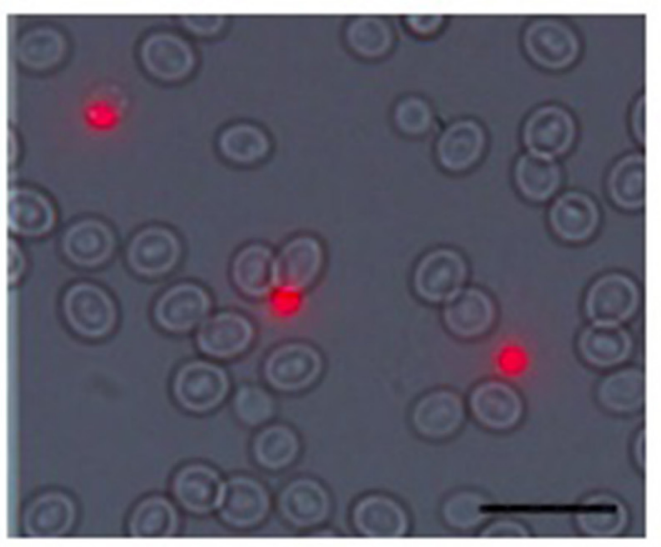

B

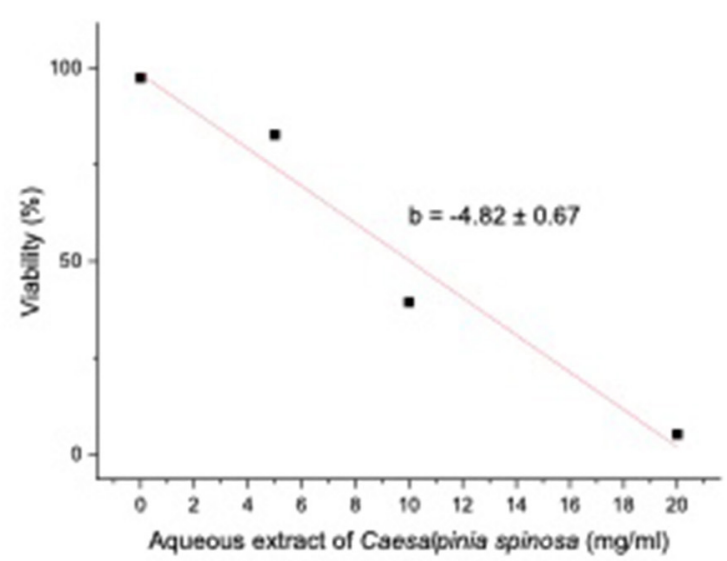

FIGURE 2 | (A) Peripheral blood erythrocytes from Oreochromis niloticus stained with propidium iodide. Dead cells can be recognized as red nuclei observed through fluorescence microscope (Olympus B51), 40×. Bar: $25 \mu \mathrm{m}$. (B) Viability ex vivo of erythrocytes from $O$. niloticus exposed to Caesalpinia spinosa aqueous extract, $\mathrm{DL}_{50}=10.50 \mathrm{mg} / \mathrm{ml}$.

three concentrations of C. spinosa extract $(0.00,0.02$, and 0.04 $\mathrm{mg} / \mathrm{ml}$ ). Water exchange was performed while maintaining the treatment conditions. After $92 \mathrm{~h}$, the final count of the survivors was determined and expressed as a percentage. Morphological deformities were also identified.

\section{Tilapia Alevin's Acute and Chronic Toxicity Assay}

Fifteen-day-old tilapia alevins, with an average weight of 0.09 $\pm 0.01 \mathrm{~g}$ and an average body length of $1.68 \pm 0.15 \mathrm{~cm}$, were used to evaluate C. spinosa toxicity. The alevins were distributed in groups of 100 individuals in each aquarium containing $260 \mathrm{~L}$ of fish culture water. The aqueous $C$. spinosa extract was added in quantities to obtain final concentrations of $0.0,0.04$, and $0.08 \mathrm{mg} / \mathrm{ml}$. Acute toxicity evaluation was performed after $96 \mathrm{~h}$ of continuous treatment, the exposure time based on those established to assess the toxicity of a substance in tilapia and chronic toxicity after 25 days (OECD Guideline for the testing of chemical, fish, juvenile growth test $=200)($ OECD Guideline for the testing of chemical, 2018). After $92 \mathrm{~h}$ and 25 days, the survivors were counted and expressed as percentages.

\section{Tilapia Adult'S Acute Toxicity Assay}

The 2.5-month-old juvenile fish, with an average weight of 48.01 $\pm 10.03 \mathrm{~g}$ and an average length of $14.17 \pm 1.68 \mathrm{~cm}$, were distributed in aquariums with a capacity of $260 \mathrm{~L}$ of water. Ten individuals per group were included in each treatment. After $48 \mathrm{~h}$ of adaptation, the treatments were started with the C. spinosa extract at concentrations of $0.0,0.04$, and $0.08 \mathrm{mg} / \mathrm{ml}$ and a positive control (cyclophosphamide $5.0 \mathrm{mg} / \mathrm{ml}$ ). After $96 \mathrm{~h}$ of treatment, the survival of the individuals was evaluated.

\section{In vivo Genotoxicity Evaluation of the $C$. spinosa Aqueous Extract in O. niloticus}

After $96 \mathrm{~h}$, the fish treated with the C. spinosa extract were anesthetized with clove oil and $0.1 \mathrm{ml}$ of blood was extracted from the caudal vein.

\section{Micronucleus Test}

Two microliters of blood was collected from each fish and cell spreading was performed on slides, allowed to dry at room temperature, fixed with $96 \%$ alcohol for $10 \mathrm{~min}$, and stained with $2 \%$ Giemsa in phosphate buffer for $30 \mathrm{~min}$ (Obiakor et al., 2014). Two thousand erythrocytes with or without micronuclei were counted on an Olympus Microscope BX41 at 1000×. The criterion to consider the presence of micronuclei was the observation of a rounded body without connection to the main nucleus and with the same coloration characteristics (Fenech et al., 2003).

\section{Comet Test}

One microliter of blood was diluted in $100 \mu \mathrm{l}$ of FBS, and 40 $\mu l$ was used for the comet assay as described above. The tail moment and percentage DNA tail were considered genotoxicity parameters using CometScore Software.

\section{Data Processing}

A data fit was performed using the normality test and variance homogeneity test between treatments. The data were expressed as the mean values of three independent experiments. Comparison of means between treatments was performed using one-way ANOVA with an additional Tukey test. Linear regression analysis was used to estimate the median lethal dose of the viability percentage of erythrocytes (ex vivo), and the results were considered statistically significant at $p<0.05$, using Origin Pro 2020 Software.

\section{RESULTS}

\section{Extraction Yield}

The yield percentage of $C$. spinosa extract was $14.93 \pm 0.31$. One thousand milliliters of water was used as the solvent. After $7 \mathrm{~h}$ of extraction at $55^{\circ} \mathrm{C}, 800 \mathrm{ml}$ of liquid extract and $3.15 \mathrm{~g} / \mathrm{ml}$ of dry extract were obtained (Table 1). 
TABLE 1 | Percentage yield of Caesalpinia spinosa aqueous extract of dried fruits.

\begin{tabular}{ccccc}
\hline $\boldsymbol{n}$ & $\begin{array}{c}\text { Fruit weight (w) } \\
\mathbf{( g )}\end{array}$ & $\begin{array}{c}\text { Dry weight (w) } \\
\mathbf{( g )}\end{array}$ & $\begin{array}{c}\% \text { Yield } \\
\mathbf{( g )}(\mathbf{w} / \mathbf{w})\end{array}$ & $\begin{array}{c}\% \text { Yield } \\
(\mathbf{m e a n}, \mathbf{g} / \mathbf{g}) \\
\mathbf{\pm} \mathbf{S D}\end{array}$ \\
\hline 1 & 200 & 29.33 & 14.67 & $14.93 \pm 0.31$ \\
2 & 200 & 30.40 & 15.20 & \\
3 & 200 & 30.40 & 15.20 & \\
4 & 200 & 29.33 & 14.67 & \\
\hline
\end{tabular}

Number of replicas $(n=4)$. \% yield = weight of dry extract $(g) *$ 100/weight of dry fruit $(g)$.

\section{Ex vivo Cytotoxicity and Genotoxicity Tests of C. spinosa in O. niloticus Blood Cells}

After standardization of procedures for in vivo and ex vivo toxicity and genotoxicity tests with samples of $O$. niloticus erythrocytes, it was possible to clearly differentiate dead and living cells up to $3 \mathrm{~h}$ outside the body (Figure $2 \mathrm{~A}$ ). The $\mathrm{LD}_{50}$ was estimated at $10.50 \mathrm{mg} / \mathrm{ml}$ and the slope (b) was $-4.82 \pm$ $0.67 \mathrm{mg} / \mathrm{ml}(p<0.05)$, with an adjusted correlation of 0.94 (Figure 2B).

Toxicity was demonstrated in O. niloticus erythrocytes. The lethality caused by the extract induced the formation of cell clusters rather than a homogeneous dispersion, as observed for the negative and positive controls.

Genetic damage in the blood cells of $O$. niloticus outside the individual provoked by the C. spinosa extract was evident, as demonstrated by the comet test. In Figure 3, the differences were noticed after observing the effects of the C. spinosa aqueous extract after $1 \mathrm{~h}$ of treatment. The comet tail lengths visibly increased at a concentration of $5.0 \mathrm{mg} / \mathrm{ml}$ in comparison with the lowest concentration, and even with those of the positive control, which indicated a clastogenic effect. The mean and median values of percentage DNA tail and tail moment were significantly higher than those of the negative control $(p<0.05)$ (Table 2).

\section{In vivo Acute Toxicity Test and Chronic Toxicity Test of C. spinosa in O. Niloticus}

The results of the in vivo tests were distinct. Toxicity tests were carried out at the level of larvae ( $\sim-10$ days old), alevins (15 days old), and juveniles ( 3 months old). In all cases, there were no deaths, behavioral changes that would indicate stress conditions, or morphological alterations of the body structure suggesting malformations were observed.

The larvae exposed to concentrations of 0.02 and $0.04 \mathrm{mg} / \mathrm{ml}$ of the C. spinosa aqueous extract showed similar reactions to the negative control. After $96 \mathrm{~h}$ of treatment, there was no mortality among the specimens, and no morphological alterations were observed; however, cyclophosphamide application caused the presence of individuals with two heads, deformations in the yolk sac, and spine deformity, at frequencies of $0.67 \%, 2.34 \%$, and $1.34 \%$, respectively (Figure 4).

The percentage of surviving fingerlings exposed to the $C$. spinosa aqueous extract for both $96 \mathrm{~h}$ and 15 days was $100 \%$. The alevins showed physical appearance of healthy fish with normal swimming group movements (shoal behavior), evident response to noise stimulation, and normal food consumption, as well as complete fins, body color, bright eyes, and transparent cornea.

The unusual presence of the approach of a video camera near the aquarium stimulated changes in the normal movements of the fish. In the negative control group, alterations were observed in the swimming of the fish in different directions, mainly toward one end of the aquarium, creating a partial dispersive confinement (Figure 5A). However, in the fish exposed to the $C$. spinosa extract, a confinement was generated mainly in one end of the aquarium (Figure 5C), followed by a recovery of the swim toward a single direction (Figures 5B,D).

The micronuclei frequency in O. niloticus erythrocytes, considering the effect of the C. spinosa aqueous extract, was similar to that of the negative control. In contrast, micronuclei frequencies in erythrocytes of individuals exposed to cyclophosphamide were clearly increased with nuclear abnormalities, nuclear buds, and segmentations, among others (Figure 6).

Similarly, in the comet assay, there were no differences among treatments with the C. spinosa aqueous extract evaluated through DNA parameters, tail percentage, and tail moment $(p>0.05)$ (Table 2).

\section{DISCUSSION}

Tannins from C. spinosa can be extracted with water alone or with water mixed with other solvents, varying the temperature from $4^{\circ} \mathrm{C}$ to $100^{\circ} \mathrm{C}$, as well as extraction times (Fenech et al., 2003). Among these processes, extraction with water prevails due to the greater amount of flavonoids and gallic acid present compared to the ethanolic extraction at $4^{\circ} \mathrm{C}$ (Skowyra et al., 2013). The presence of a high content of flavonoids and gallic acid in the aqueous extract obtained with water at $55^{\circ} \mathrm{C}$ for $7 \mathrm{~h}$ can be assumed.

The safety of $C$. spinosa extract is essential for cosmetic and/or pharmaceutical applications and, to evaluate its toxic and genotoxic activities, $O$. niloticus constitutes an ideal species as a biological model for ex vivo and in vivo studies because of its convenience of handling, low cost, and, in particular, its high sensitivity to xenobiotic agents.

\section{Ex vivo Cytotoxicity and Genotoxicity Assay of C. spinosa in O. niloticus Blood Cells}

For ex vivo testing of the cytotoxic and genotoxic effects of $C$. spinosa aqueous extract on tilapia peripheral blood erythrocytes (caudate vein), it is essential to preserve the blood cells. We concurred with Ramsdorf et al. (2009) in the use of FBS as an adequate preservative. Erythrocyte viability was maintained for $3 \mathrm{~h}$ at room temperature $\left(24^{\circ} \mathrm{C} \pm 2^{\circ} \mathrm{C}\right)$ in percentages $>90 \%$. With the PBS and Hank's solutions, we obtained $>50 \%$ dead cells, normally unfeasible for the comet assay, which is generally not recommended for use in the preservation of tilapia blood samples.

Toxicity and DNA damage due to the effect of C. spinosa extract on isolated erythrocytes from peripheral blood of $O$. 
A

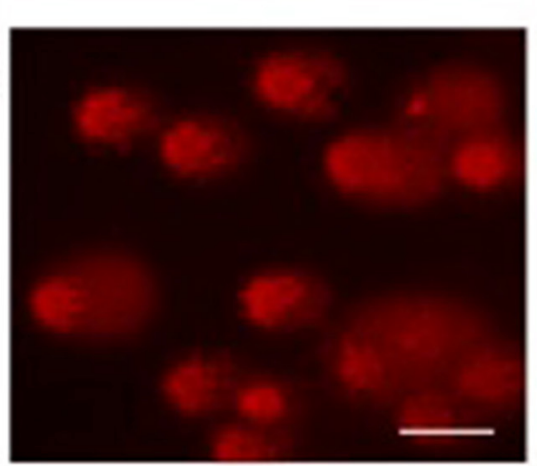

C

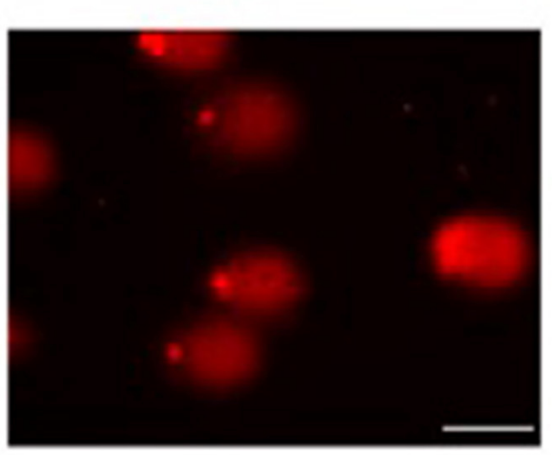

E

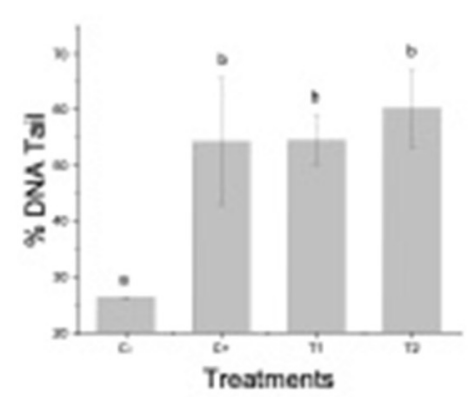

B

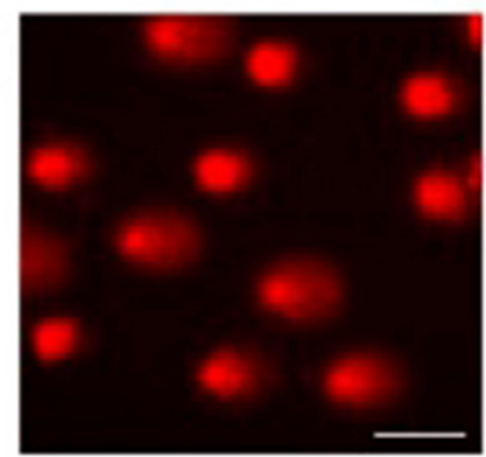

D

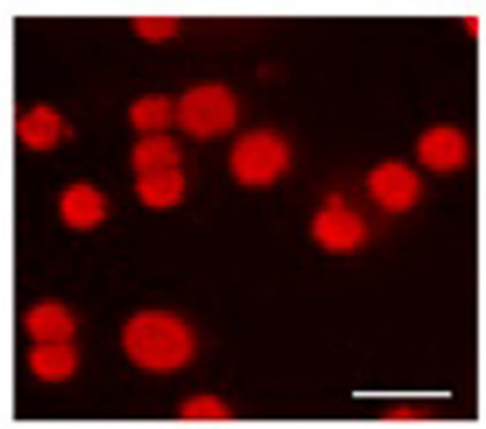

$\mathbf{F}$

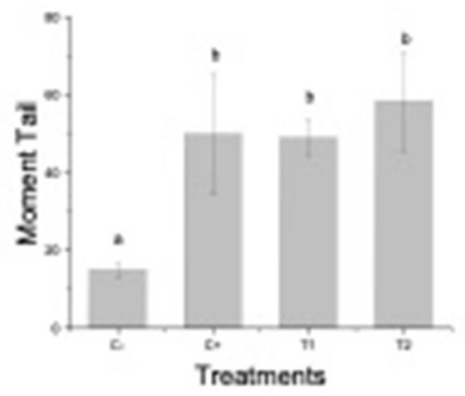

FIGURE 3 | Ex vivo testing of Oreochromis niloticus erythrocytes by the comet assay. (A) Caesalpinia spinosa 5.0 mg/ml. (B) C. spinosa 2.5 mg/ml. (C) Positive control (cyclophosphamide $1.25 \mu \mathrm{g} / \mathrm{ml}$ ). (D) Negative control. Bar $50 \mu \mathrm{m}$. (E) \%DNA Tail and (F) Moment Tail (C- Negative control; C+ Positive control; T1 and T2, C. spinosa 2.5 and $5.0 \mathrm{mg} / \mathrm{ml}$, respectively). Same letters mean no significant differences.

niloticus were evident in all the experimental tests performed on samples from the same and different individuals. No ex vivo or similar tests have been reported in other cell types; however, the effects of C. spinosa extract on tumor cell lines in in vitro tests have been documented (Castaneda et al., 2012; Sandoval et al., 2016; Urueña et al., 2020).

An important investigation is the immunomodulatory activity of C. spinosa in a culture of human dendritic cells, which revealed increased levels of proteins and mRNA of pro-inflammatory cytokines, including IL-1 $\beta$, IL-6, IL-8, IL-12p70, and TNF- $\alpha$ (Santander et al., 2011). The functional change of the cells would make them permeable to the compounds from the C. spinosa extract, causing toxicity and DNA damage. Ex vivo and in vitro cytotoxicity and genotoxicity tests require conditions similar to those in vivo, which cannot be fully imitated. Therefore, changes in cells to artificial environments modify their functional activity (Tice et al., 2000). This situation was demonstrated in bacterial cells when cultivation under anoxic conditions increased the membrane potential and the propidium iodide dye entered the intracellular space, which would not occur in in vivo conditions (Kirchhoff and Cypionka, 2017).

\section{In vivo Acute Toxicity Test and Chronic Toxicity Test of $C$. spinosa in $O$. niloticus}

The contrasting results from cytotoxicity and genotoxicity in the ex vivo tests $v s$. the absence of toxicity in the in vivo tests could be explained by the complexity and sensitivity of the cell structure, 

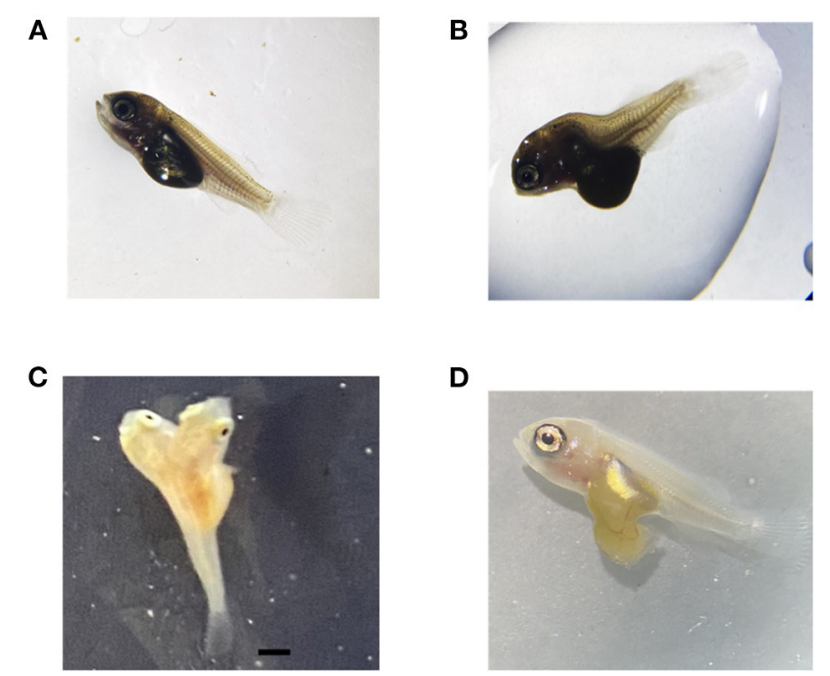

FIGURE 4 | Oreochromis niloticus larvae. (A) Normal, exposed to Caesalpinia spinosa aqueous extract. (B-D) Positive control (cyclophosphamide

$1.25 \mu \mathrm{g} / \mathrm{ml})$, spinal malformation, larvae with two heads, and malformed yolk sac, respectively (Stereoscope MOTIC, SMZ-168, China,1.5×, View a and b with backlight, view $\mathrm{c}$ and $\mathrm{d}$ with light outside). Bar: $1 \mathrm{~mm}$.

TABLE 2 | \%DNA Tail and Moment Tail in Oreochromis niloticus erythrocytes treated with C. spinosa extract, cyclophosphamide (positive control), and fish culture water (negative control).

\begin{tabular}{lrr}
\hline Treatments & \%DNA Tail & Moment Tail \\
\hline Negative Control & $23.58 \pm 10.49^{\mathrm{a}}$ & $8.29 \pm 6.01^{\mathrm{a}}$ \\
C. spinosa aqueous extract $(0.04 \mathrm{mg} / \mathrm{ml})$ & $20.38 \pm 1.53^{\mathrm{a}}$ & $5.85 \pm 1.84^{\mathrm{a}}$ \\
C. spinosa aqueous extract $(0.08 \mathrm{mg} / \mathrm{ml})$ & $26.14 \pm 5.10^{\mathrm{a}}$ & $8.17 \pm 4.40^{\mathrm{a}}$ \\
Positive Control & $31.20 \pm 3.45^{\mathrm{b}}$ & $18.57 \pm 2.99^{\mathrm{b}}$ \\
\hline
\end{tabular}

Different letters in the same column show statistical differences $(p<0.05)$.

which refers to the semi-permeability of the cell membrane. The mechanisms for entry and exit regulating the existing structurally designed biomolecules from the plasma membrane have not been fully explained (Bozelli and Epand, 2020). Cellular differences vs. chemical signaling are other characteristics that confer differences according to the tissue in which they are found and the function they perform. Any change in genetic regulation or changes in its functionality in situ or ex situ will generate alterations in membrane permeability, as in the case of quantitative transmembrane glycoprotein changes in cancer cell membranes (Fu et al., 2019).

Although the most susceptible stages of the fish life cycle are the embryonic and larval, due to the replication and transcription cycles that regulate the organogenesis processes (Sfakianakis et al., 2015), the larvae exposed to C. spinosa aqueous extract $(0.02$ and $0.04 \mathrm{mg} / \mathrm{ml})$ showed healthy development, supported by the determined parameters. The larval development speed was not affected by any of the treatments with the C. spinosa aqueous extract. The positive control (cyclophosphamide) had no alteration in viability due to the very low concentration,
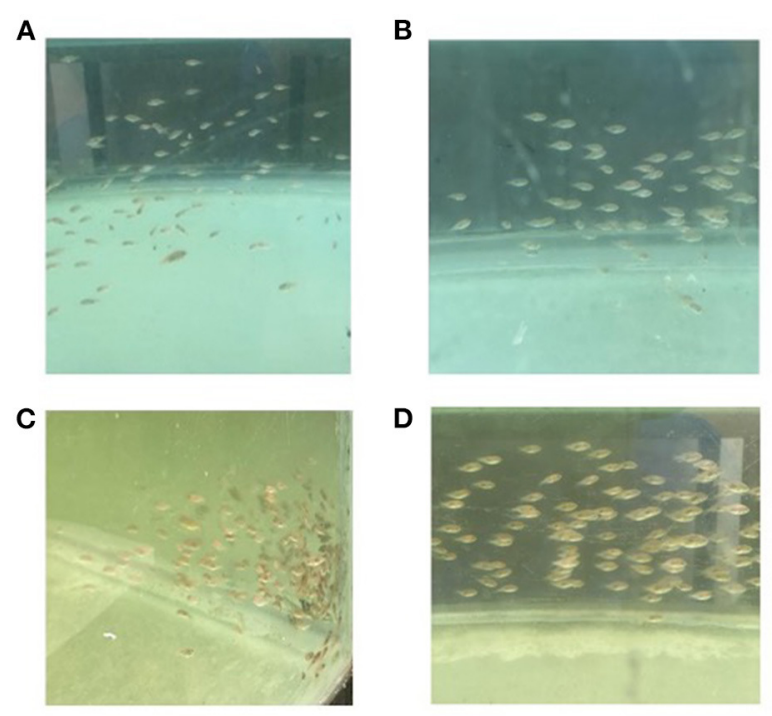

FIGURE 5 | Group behavior of tilapia Oreochromis niloticus alevins in aquarium. (A, B). Negative control (culture water). (C, D) Treatment with Caesalpinia spinosa aqueous extract.

although visible malformations were evident in the larval body structure. The individuals with abnormalities, as well as a minority group with alterations in swimming behavior remained in the lower part of the incubator, denoted by difficulty in swimming or delay in development progress (Sarikaya and Selvi, 2005). The indicators of changes in tilapia larval development processes in the positive control were consistent with the reports of exposure to genotoxic contaminants (Mao et al., 2020). Behavioral changes are the most sensitive indication of potential toxic effects (Sarikaya and Selvi, 2005), and according to our results, we have confirmed the absence of damage.

Fingerlings (10-15 days post-larvae) exposed to the C. spinosa extract had visibly normal health. To consider the state of visible health of the fish or situations that cause stress in the rearing environment, the parameters to be considered are morphology or physical appearance, and behavior in swimming activity (Martins et al., 2012). Conducting an environmental disturbance either by distributing food or confinement (Sadoul et al., 2014), as in this case, induced a reaction by the fish to the sudden presence of a video recording. Fish swimming activity in the water treated with the $C$. spinosa extract indicated that the fish were not toxically affected. Faced with the sudden presence, by recording or feeding, the fish had a normal reaction. In both cases, fish escaped toward one end of the aquarium. In the control, the escape was partially dispersive, and in the treatment with C. spinosa extract, the escape was in a group followed by a rapid recovery and swimming of the group in one direction. This treatment did not have a stressful effect or caused any death of the alevins after 4 and 25 days of continuous treatment. Another peculiarity of this treatment was the improvement of water quality by precipitating algae or residues of uneaten food. 
A

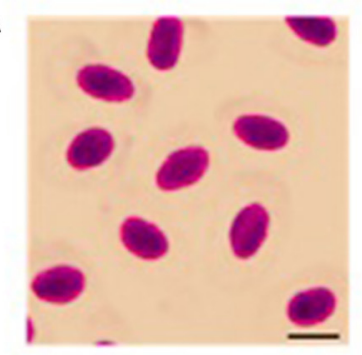

C
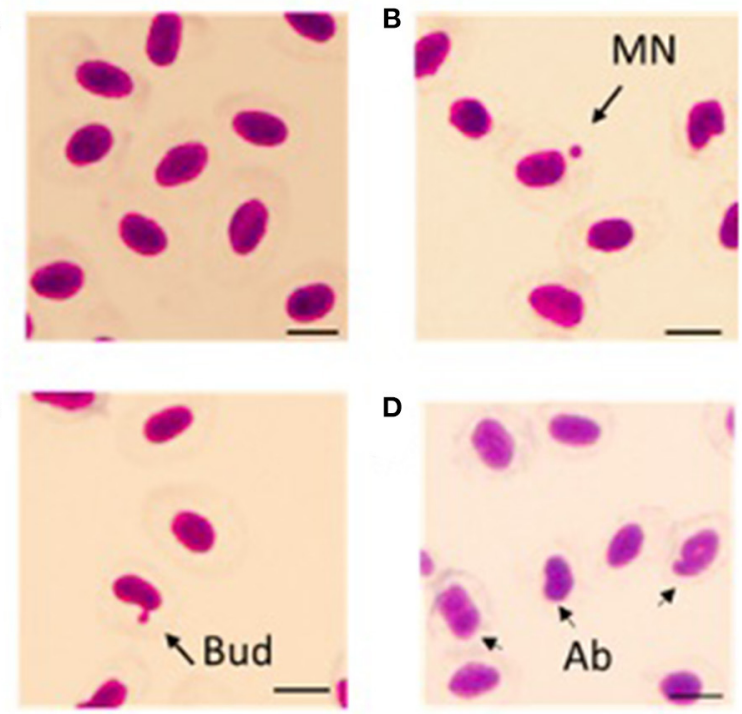

D

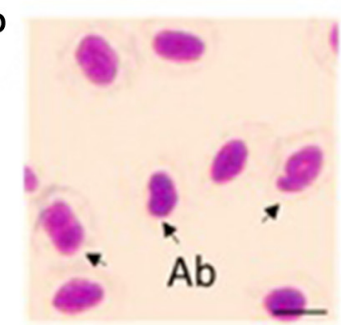

E

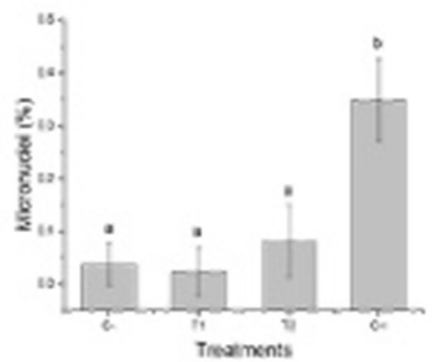

FIGURE 6 | Oreochromis niloticus erythrocytes stained with Giemsa observed under an Olympus Microscope, BX41, Japan, 1000×. (A) Normal erythrocytes. (B) Micronucleus (MN). (C) Bud: Nuclear Bud. (D). Ab: nuclear abnormalities. Bar: $20 \mu \mathrm{m}$. (E) Micronuclei (\%), same letters mean no significant differences (Tukey test: $p<0.05$ ).

Juvenile tilapia are often used as biological models in genotoxic assays with reliable results because of their nucleated erythrocytes, the ability to work with a small amount of sample, and their compatibility with international ethical standards (Brendler-Schwaab et al., 2005). Among the parameters that determine genotoxicity, the working group of the 6th International Workshop on Genotoxicity Testing (IWGT) held in Foz de Iguazú, Brazil, 2013 (Speit et al., 2015) concluded that the combination/integration of the in vivo $\mathrm{MN}$ assay and the in vivo comet assay through estimates of tail intensity (percentage DNA tail) and tail timing (MT) are adequate for detecting DNA-damaging agents (Tice et al., 2000).

As in the previous stages of the tilapia life cycle, the results in the juveniles were similar, with no effect on the viability or well-being of the fish. In the positive control, the presence of micronuclei, nuclear buds, and nuclear abnormalities were evident at significant frequencies with respect to the treatments with the C. spinosa extract. According to the specialized literature, the C. spinosa ethanolic extract obtained from the pods administered orally (nasogastric tube) to mice, at concentrations

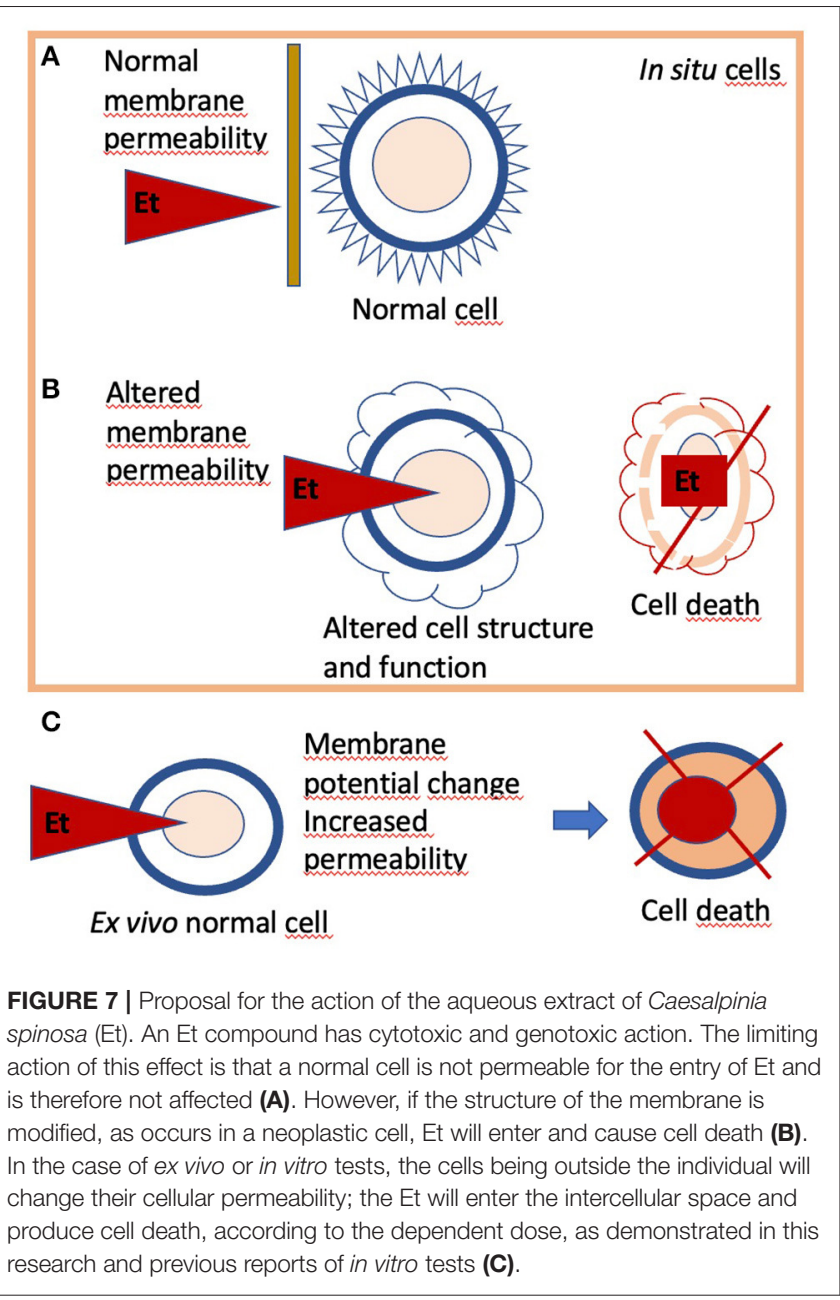

of 500 to $2,000 \mathrm{mg} / \mathrm{kg}$ of body weight, did not differ from the negative control. Similarly, the Ames test demonstrated the absence of mutations in the C. spinosa ethanolic extract (Ballesteros-Ramírez et al., 2021).

From these tests, we deduced that there was a bioactive compound or a mixture of compounds in the C. spinosa aqueous extract that had toxic and genotoxic activities. If such compounds cross the membrane, due to changes in the membrane potential or other mechanisms that alter its permeability, as is the case with tumor cells, the C. spinosa extract, upon entering the intracellular environment, may induce apoptosis and cell death (Figure 7). This proposal could be explained by the results of Gomez-Cadena et al. (2016), Prieto et al. (2018), who reported a reduction in tumors in mice treated with the C. spinosa ethanolic extract.

The complexity of the active compounds present in the aqueous and ethanolic extracts of C. spinosa pods remains unresolved. In general, polyphenols, flavonoids, tannic acids, and gallic acids (Aguilar-Galvez et al., 2014; Mu et al., 2016), along with 10 types of sesquiterpenoids, have been identified in the extract of mature pods, including Caesalpinin A(1) (Mu et al., 2016) in extracts of immature pods, galactomannan (polysaccharides) (Santander et al., 2011; Skowyra et al., 2013) in 
seed endosperm, and diterpenes in extracts of leaves (He et al., 2015). From our results, it can be inferred that as long as the structure and function of normal cells were maintained, there was no risk of DNA damage due to the active compounds from $C$. spinosa aqueous extract. Therefore, according to the properties cited in previous studies, the extract of C. spinosa pods could potentially be considered safe for use in dermocosmetic products.

This study was restricted to the cytotoxic and genotoxic evaluation of cells from $O$. niloticus in ex vivo and in vivo tests of $C$. spinosa aqueous extract. It is important to conduct further studies on the characterization of the extract constituents and to perform independent tests of the active ingredients.

\section{CONCLUSIONS}

In conclusion, the C. spinosa aqueous extract exhibited toxicity and genotoxic activity that acted on ex vivo exposed cells, as demonstrated by the blood cells obtained from the peripheral blood of $O$. niloticus. In contrast, in the in vivo evaluation, the aqueous extract did not cause mortality, or phenotypic changes in morphology or behavior evaluated at different stages of the biological cycle (larvae, fingerlings, and juveniles). Similarly, the absence of genotoxicity was demonstrated by the micronucleus tests and the comet assay of blood samples from individuals exposed to the aqueous extract continuously for $96 \mathrm{~h}$. Further research is required to consider the characteristics of the compounds present in the C. spinosa extract and the mechanisms of cytotoxic and genotoxic action in cells ex vivo and in vitro. The reported properties in specialized literature and the safety profile of C. spinosa aqueous extract potentiate it as a resource to be considered for inclusion in dermocosmetic and topical pharmaceutical products.

\section{REFERENCES}

Aguilar-Galvez, A., Noratto, G., Chambi, F., Debaste, F., and Campos, D. (2014). Potential of tara (Caesalpinia spinosa) gallotannins and hydrolysates as natural antibacterial compounds. Food Chem. 156, 301-304. doi: 10.1016/j.foodchem.2014.01.110

Ballesteros-Ramírez, R., Durán, M. I., and Fiorentino, S. (2021). Genotoxicity and mutagenicity assessment of a standardized extract (P2Et) obtained from Caesalpinia spinose. Toxicol. Rep. 8, 258-263. doi: 10.1016/j.toxrep.2020.12.024

Bivehed, E., Soderberg, O., and Hellman, B. (2020). Flash-comet: significantly improved speed and sensitivity of the comet assay through the introduction of lithium-based solutions and a more gentle lysis. Mut. Res. Gene. Toxicol. Environ. Mutagene. 858-860:503240. doi: 10.1016/j.mrgentox.2020.503240

Bouabid, K., Lamchouri, F., Toufik, H., Sayah, K.,., Cherrah, Y., et al. (2018). Phytochemical screening and in vitro evaluation of alpha amylase, alpha glucosidase and beta galactosidase inhibition by aqueous and organic Atractylis gummifera L. extracts. Plant Sci.Today 5, 103-112. doi: 10.14719/pst.2018.5.3.393

Bozelli, J. C., and Epand, R. M. (2020). Membrane shape and the regulation of biological processes. J. Mol. Biol. 432, 5124-5136. doi: 10.1016/j.jmb.2020.03.028

Brendler-Schwaab, S., Hartmann, A., Pfuhler, S., and Speit, G. (2005). The in vivo comet assay: use and status in genotoxicity testing. Mutagenesis 20, 245-254. doi: $10.1093 /$ mutage/gei033

Callohuari, R., Sandoval, V. M., and Huamán, G. O. (2017). Efecto gastroprotector y capacidad antioxidante del extracto acuoso de las vainas de Caesalpinia

\section{DATA AVAILABILITY STATEMENT}

The raw data supporting the conclusions of this article will be made available by the authors, without undue reservation.

\section{ETHICS STATEMENT}

The animal study was reviewed and approved by 010-2021-CEFac.CC.BB/UNT, (Universidad Nacional de Trujillo).

\section{AUTHOR CONTRIBUTIONS}

$\mathrm{ZP}$ and $\mathrm{AB}$ : conceptualization. DS, LS-T, NR-P, and MA: methodology. AB, DS, CA, and AC: formal analysis. $\mathrm{ZP}, \mathrm{AB}$, and $\mathrm{DS}$ : investigation. $\mathrm{ZP}$ and $\mathrm{AB}$ : writing-original draft preparation. $\mathrm{AB}$ and $\mathrm{RM}$ : writing-review and editing. $\mathrm{ZP}$ and $\mathrm{CA}$ : supervision and project administration. $\mathrm{ZP}$ and $\mathrm{AB}$ : funding acquisition. All authors have read and agreed to the published version of the manuscript.

\section{FUNDING}

The authors thank CONCYTEC-FONDECYT, process E041-01 (Contract number 123-2018-FONDECYT-BM-IADT/AV), and Conselho Nacional de Desenvolvimento Científico e Tecnológico (CNPq, Process 305250/2019-1).

\section{ACKNOWLEDGMENTS}

The authors are greatly thankful to Luz Argomedo, biologist, for her help with the Micronucleus Test.

spinosa 'tara', en animales de experimentación. An. Fac. Med. 78, 61-66. doi: 10.15381/anales.v78i1.13023

Capela, R., Garric, J., Castro, L. F. C., and Santos, M. M. (2019). Embryo bioassays with aquatic animals for toxicity testing and hazard assessment of emerging pollutants: a review. Sci. Total Environ. 705:135740. doi: 10.1016/j.scitotenv,.2019.135740

Castaneda, M. D., Pombo, D. L., Uruena, C., Hernandez, J., and Fiorentino, S. (2012). A gallotannin-rich fraction from Caesalpinia spinosa (Molina) Kuntze displays cytotoxic activity and raises sensitivity to doxorubicin in a leukemia cell line. BMC Complement Altern. Med. 12:38. doi: 10.1186/1472-6882-12-38

Chambi, F., Chirinos, R., Pedreschi, R., Betalleluz-Pallardel, I., Debaste, F., and Campos, D. (2013). Antioxidant potential of hydrolyzed polyphenolic extracts from tara (Caesalpinia spinosa) pods. Ind. Crops Prod. 47, 168-175. doi: 10.1016/j.indcrop.2013.03.009

de Melo, M. O., and Maia Campos, P. M. B. G. (2019). Application of biophysical and skin imaging techniques to evaluate the film-forming effect of cosmetic formulations. Int. J. Cosmet. Sci. 41, 579-584. doi: 10.1111/ics.12577

Fenech, M., Chang, W., Kirsch-Volders, M., Holland, N., Bonassi, S., and Zeiger, E. (2003). HUMN project: detailed description of the scoring criteria for the cytokinesis-block micronucleus assay using isolated human lymphocyte cultures. Mut. Res. Gene. Toxicol. Environ. Mutagene. 534, 65-75. doi: 10.1016/S1383-5718(02)00249-8

Fu, Y., Jing, Y., Gao, J., Li, Z., Wang, H., Cai, M., et al. (2019). Variation of Trop2 on non-small-cell lung cancer and normal cell membranes revealed by super-resolution fluorescence imaging. Talanta 207:120312. doi: 10.1016/j.talanta.2019.120312 
Gomez-Cadena, A., Urueña, C., Prieto, K., Martínez-Usatorre, U., Donda, U., Barreto, A., et al. (2016). Immune-system-dependent anti-tumor activity of a plant-derived polyphenol rich fraction in a melanoma mouse model. Cell Death Dis. 7:e2243. doi: 10.1038/cddis.2016.134

Goycochea, R. R. A. (2010). Evaluación de taninos y goma del fruto de la Tara Caesalpinia spinosa (Molina) Kuntze provenientes de las lomas de Atiquipa, Arequipa - Perú. Tesis para optar el Título de Ingeniero Forestal, Facultad de Ciencias Forestales. Universidad Nacional Agraria La Molina, Lima, Perú.

He, D., Li, Y., Tang, H., Ma, R., Li, X., and Wang, L. (2015). Six new cassane diterpenes from the twigs and leaves of Tara (Caesalpinia spinosa Kuntze). Fitoterapia 105, 273-277. doi: 10.1016/j.fitote.2015.07.018

Hussain, B., Sultana, T., Sultana, S., Masoud, M. S., Ahmed, Z., and Mahboob, S. (2018). Fish eco-genotoxicology: comet and micronucleus assay in fish erythrocytes as in situ biomarker of freshwater pollution. Saudi J. Biol. Sci. 25, 393-398. doi: 10.1016/j.sjbs.2017.11.048

Kirchhoff, C., and Cypionka, H. (2017). Propidium ion enters viable cells with high membrane potential during live-dead staining. J. Microbiol. Methods 142, 79-82. doi: 10.1016/j.mimet.2017.09.011

Lasso, P., Gomez-Cadena, A., Urueña, C., Donda, A., Martinez-Usatorre, A., Romero, P., et al. (2020). An immunomodulatory gallotanin-rich fraction from Caesalpinia spinosa enhances the therapeutic effect of anti-PD-L1 in melanoma. Front. Immunol. 11:584959. doi: 10.3389/fimmu.2020.584959

Lubbe, A., and Verpoorte, R. (2011). Cultivation of medicinal and aromatic plants for specialty industrial materials. Ind. Crops Prod. 34, 785-801. doi: 10.1016/j.indcrop.2011.01.019

Mao, L., Jia, W., Zhang, L., Zhang, Y., Zhu, L., Sial, M. U., et al. (2020). Embryonic development and oxidative stress effects in the larvae and adult fish livers of zebrafish (Danio rerio) exposed to the strobilurin fungicides, kresoxim-methyl and pyraclostrobin. Sci. Total Environ. 729:139031. doi: 10.1016/j.scitotenv.2020.139031

Martins, C. I. M., Galhardo, L., Noble, C., Damsgård, B., Spedicato, M. T., Zupa, W., et al. (2012). Behavioural indicators of welfare in farmed fish. Fish Physiol. Biochem. 38, 17-41. doi: 10.1007/s10695-011-9518-8

Mohammad-Azmin, S. N. H., and Mat-Nor, M. S. (2020). Chemical fingerprint of Centella asiatica's bioactive compounds in the ethanolic and aqueous extracts. Adv Biomark Sci Technol. 2, 35-44. doi: 10.1016/j.abst.2020.10.001

Mu, W., Tang, H., Li, Y., He, D., Ma, R., and Wang, L. (2016). Caesalpinone A, a new type of gorgonane sesquiterpenoid containing an unprecedented 1,15bridge, from the pods of Caesalpinia spinosa Kuntze. Fitoterapia 112, 233-236. doi: 10.1016/j.fitote.2016.06.012

Obiakor, M. O., Okonkwo, J. C., and Ezeonyejiaku, C. D. (2014). Genotoxicity of freshwater ecosystem shows DNA damage in preponderant fish as validated by in vivo micronucleus induction in gill and kidney erythrocytes. Mut. Res. Gene. Toxicol. Environ. Mutagene. 775-776, 20-30. doi: 10.1016/j.mrgentox.2014.09.010

OECD Guideline for the testing of chemical (2018). Fish, Juvenile Growth Test $=200$. 11th Version. Available online at: http://www.oecd.org/ chemicalsafety/testing/Draft\%20Update\%20TG\%20203_July\%202018-for \%20public\%20comments.pdf (accessed July, 2018).

Olmedo-Juárez, A., Briones-Robles, T. I., Zaragoza-Bastida, A., Zamilpa, A., Ojeda-Ramírez, D., Mendoza de Gives, P., et al. (2019). Antibacterial activity of compounds isolated from Caesalpinia coriaria (Jacq) Willd against important bacteria in public health. Microb. Pathog. 136:103660. doi: 10.1016/j.micpath.2019.103660

Prieto, Z., Salirrosas, D., Sánchez-Tuesta, L., and Arqueros, M. (2018). El extracto de Caesalpinia spinosa inhibe la infección in vivo de Flavobacterium columnare en tilapia. Sci. Agropecuaria 9, 215-221. doi: 10.17268/sci.agropecu.2018.02.06

Ramsdorf, W. A., Guimarães, F. de S. F., Ferraro, M. V. M., Gabardo, J., Trindade, E. da S., and Cestari, M. M. (2009). Establishment of experimental conditions for preserving samples of fish blood for analysis with both comet assay and flow cytometry Mut. Res. Gene. Toxicol. Environ. Mutagene.673, 78-81. doi: 10.1016/j.mrgentox.2008.11.010

Sadoul, B., Mengues, E. P., Friggens, N. C., Prunet, P., and Colson, V. (2014). A new method for measuring group behaviours of fish shoals from recorded videos taken in near aquaculture conditions. Aquaculture 430, 179-187. doi: 10.1016/j.aquaculture.2014.04.008

Sandoval, T. A., Urueña, C. P., Llano, M., Gómez-Cadena, A., Hernández, J. F., Sequeda, L. G., et al. (2016). Standardized extract from Caesalpinia spinosa is cytotoxic over cancer stem cells and enhance anticancer activity of doxorubicin. Am. J. Chin. Med.44, 1693-1717. doi: 10.1142/S0192415X16500956

Santander, S. P., Aoki, M., Hernandez, J. F., Pombo, M., Moins-Teisserenc, H., Mooney, N., et al. (2011). Galactomannan from Caesalpinia spinosa induces phenotypic and functional maturation of human dendritic cells. Int. Immunopharmacol. 11, 652-660. doi: 10.1016/j.intimp.2011.01.006

Sarikaya, R., and Selvi, M. (2005). Investigation of acute toxicity of (2,4dichlorophenoxy) acetic acid (2,4-D) herbicide on larvae and adult Nile tilapia (Oreochromis niloticus L). Environ. Toxicol. Pharmacol. 20, 264-268. doi: 10.1016/j.etap.2005.01.006

Sfakianakis, D. G., Renieri, E., Kentouri, M., and Tsatsakis, A. M. (2015). Effect of heavy metals on fish larvae deformities: a review. Environ. Res. 137, 246-255. doi: 10.1016/j.envres.2014.12.014

Skowyra, M., Falguera, V., Gallego, G., Peiró, S., and Almajano, M. P. (2013). Antioxidant properties of aqueous and ethanolic extracts of tara (Caesalpinia spinosa) pods in vitro and in model food emulsions. J. Sci. Food Agric. 94, 911-918. doi: 10.1002/jsfa.6335

Speit, G., Kojima, H., Burlinson, B., Collins, A. R., Kasper, P., Plappert-Helbig, U., et al. (2015). Critical issues with the in vivo comet assay: a report of the comet assay working group in the 6th International Workshop on Genotoxicity Testing (IWGT). Mut. Res. Gene. Toxicol. Environ. Mutagen. 783, 6-12. doi: 10.1016/j.mrgentox.2014.09.006

Tice, R., Agurell, E., Anderson, D., Burlinson, B., Hartmann, A., Kobayashi, H. et al. (2000). Single cell gel/comet assay: guidelines for in vitro and in vivo genetic toxicology testing R. Environ.Mol. Mutagen. 35, 206-222. doi: 10.1002/ (sici) 1098-2280(2000)35:3<206::aid-em8>3.0.co;2-j

Urueña, C., Sandoval, T. A., Lasso, P., Tawil, M., Barreto, A., Torregrosa, L., et al. (2020). Evaluation of chemotherapy and P2Et extract combination in ex vivo derived tumor mammospheres from breast cancer patients. Sci. Rep. 10:19639. doi: 10.1038/s41598-020-76619-9

Valachová, K., Topolská, D., Nagy, M., Gaidau, C., Niculescu, M., Matyašovský, J., et al. (2014). Radical scavenging activity of Caesalpinia spinosa. Neuro Endocrinol. Lett. 35, 197-200.

Conflict of Interest: The authors declare that the research was conducted in the absence of any commercial or financial relationships that could be construed as a potential conflict of interest.

Publisher's Note: All claims expressed in this article are solely those of the authors and do not necessarily represent those of their affiliated organizations, or those of the publisher, the editors and the reviewers. Any product that may be evaluated in this article, or claim that may be made by its manufacturer, is not guaranteed or endorsed by the publisher.

Copyright (C) 2021 Salirrosas, Reategui-Pinedo, Crespo, Sánchez-Tuesta, Arqueros, Cabrera, Martinez, Ayala, Baby and Prieto. This is an open-access article distributed under the terms of the Creative Commons Attribution License (CC BY). The use, distribution or reproduction in other forums is permitted, provided the original author(s) and the copyright owner(s) are credited and that the original publication in this journal is cited, in accordance with accepted academic practice. No use, distribution or reproduction is permitted which does not comply with these terms. 